\title{
Leishmaniasis in Northern Syria during Civil War
}

\author{
Khalid Rehman, Julia Walochnik, Johannes Mischlinger, \\ Bodour Alassil, Richard Allan, Michael Ramharter
}

Since the onset of the ongoing civil war in Syria, the governmental surveillance system for leishmaniasis has lost access to provinces of northern Syria. The MENTOR Initiative, an international not-for-profit organization, was commissioned to implement an integrated leishmaniasis control program, providing an opportunity to reassess the epidemiology of leishmaniasis in northern Syria. Epidemiologic data and biologic samples for molecular species diagnostics were collected from collaborating local health centers. Incidence peaked in March 2015 at 7,743 estimated monthly cases. High levels of transmission were observed in traditional endemic regions but extended to previously hypoendemic regions, such as Al-Raqqa and Al-Hasakah. Incidence decreased to 3,209 in July 2015. Data indicate that the prewar trend of increasing incidence of cutaneous leishmaniasis accelerated during the beginning of armed conflict but declined after implementation of the comprehensive control program by the MENTOR Initiative. Molecular analysis revealed a spectrum of Leishmania species and sporadic cases of visceral leishmaniasis.

$\mathrm{L}$ eishmaniasis is caused by different Leishmania species. The infection may be cutaneous, mucocutaneous, or visceral, depending on the species involved and the immune status of the patient. The common term Aleppo boil indicates the historic importance of cutaneous leishmaniasis (CL) in Syria. Before the ongoing civil war began, the national leishmaniasis control program in Syria delegated general treatment responsibilities to primary healthcare centers (HCCs) and other health services of the governmental health system. Official World Health Organization (WHO) statistics indicate that $\approx 14,000$ new CL cases occurred per year during 1994-2000. Incidence increased after that, to 27,825 in 2010 . In addition to the main burden of CL, sporadic cases of visceral leishmaniasis (VL) (25-55 cases/y) were reported to governmental authorities (1).

Author affiliations: Medical University of Vienna, Vienna, Austria

(K. Rehman, J. Walochnik, J. Mischlinger, M. Ramharter);

Bernhard Nocht Institute for Tropical Medicine, Hamburg,

Germany (J. Mischlinger, M. Ramharter); University Medical Center

Hamburg-Eppendorf, Hamburg (J. Mischlinger, M. Ramharter);

The MENTOR Initiative, West Sussex, UK (B. Alassil, R. Allan)

DOI: https://doi.org/10.3201/eid2411.172146
After the onset of civil war, reports emerged about a dramatic increase in CL cases in Syria and neighboring Jordan (2-4). These reports were based largely on anecdotal observations of clinical cases in refugees from Syria. However, because of a loss of access of governmental authorities to leishmaniasis-endemic regions within Syria, no reliable epidemiologic data have been recorded and published since the onset of the civil war. In addition, international organizations initially providing treatment structures for CL within Syria operated with conflicting case definitions and reporting systems for leishmaniasis, thus bringing forth unreliable epidemiologic data.

The MENTOR Initiative (http://thementorinitiative.org), an international humanitarian organization, was commissioned by the US Agency for International Development and UK Department for International Development to plan and implement a comprehensive leishmaniasis control program in northern Syria. The organization's principal aim is to relieve tropical diseases in humans, with a focus on vectorborne diseases in the context of complex emergencies. Activities in Syria were launched in September 2013, and a comprehensive control program was set up with both a preventive and a curative component. To provide firm evidence for the magnitude of the leishmaniasis epidemic and to accompany and evaluate the rollout of the leishmaniasis control program, an epidemiologic surveillance system was established. The principal aims of this system were to collect reliable data for the epidemiology of leishmaniasis, to investigate the comparative distribution of Leishmania species in clinical samples, and to evaluate diagnostic and therapeutic activities of affected populations in northern Syria.

\section{Materials and Methods}

The leishmaniasis control program was based on current WHO recommendations for integrated vector control management (5) aimed at reducing both the vector density and parasite reservoirs. Sand fly populations were targeted by large-scale implementation of indoor residual spraying, provision of long-lasting insecticide-treated nets, long-lasting insecticide-treated curtains, and waste management. The leishmanial parasite reservoir was targeted by providing curative services for local populations. 


\section{Organizational Setup, Study Area, and Health Infrastructure}

Because of the precarious, ever-changing security situation in northern Syria, the MENTOR Initiative opted to not deploy external, international personnel into the conflict zone. A headquarters for coordination of activities was set up in the border region between Syria and Turkey. Implementation of the control program was based on voluntary collaboration of local Syrian HCCs, which had been detached from governmental administration and supply since the onset of the civil war. Healthcare workers in Syria were invited to travel to the mission's headquarters, where they were offered logistical support and training in the diagnosis and treatment of CL and VL. Pentavalent antimonial therapy was provided to healthcare workers for treating patients at their HCCs.

\section{Collection of Epidemiologic Data for Northern Syria Provinces}

Epidemiologic, clinical, and demographic data were collected from all collaborating HCCs in the target regions. Healthcare workers cleaned lesions with antiseptic solutions and then scraped the margins of ulcerated wounds with sterile lancets. The scraped material was transferred to a glass slide, then fixed with methanol and stained with Giemsa stain. Diagnosis of CL was established by trained healthcare workers at each HCC. Where appropriate laboratory facilities were available, healthcare workers used light microscopy to detect amastigote forms of Leishmania spp. $(6,7)$. Rapid tests (IT-LEISH Individual Rapid Test; Bio-Rad Laboratories, Hercules, CA, USA) were used for diagnosis of VL (8).

\section{Molecular-Epidemiologic Survey of Cutaneous Leishmaniasis at Sentinel Sites}

For confirmation of the accuracy of the HCC diagnostic services and to obtain molecular-epidemiologic evidence, skin samples were collected at sentinel sites and transported to headquarters for further analysis. Two representative sentinel sites were selected for this molecular epidemiologic substudy in the provinces of Idlib (Heish HCC) and Aleppo (Batranah HCC).

Heish HCC was located in rural Idlib in a district called Al Ma'ra. During the survey period in 2015, the catchment population of this HCC was 5,933, and the population of internally displaced persons (IDPs) was 1,367. Most of the IDPs had come from Hama and southern Aleppo, because Heish was relatively secure in comparison with those areas. Batranah HCC was located in the Jebel Saman district in southeastern Aleppo. The catchment area of this HCC had a population of $\approx 3,500$, with $<500$ IDPs. All patients who arrived at these sites during the period of molecular data collection were invited to participate.
Sampling involved first the cleaning of the affected skin with moistened gauze. Then, sterile filter paper was pressed against the moist base and the margins of the ulcer to allow for absorbing wound secretions $(9,10)$.

\section{Molecular Analysis of Skin Samples}

Biologic samples were shipped to the Medical University of Vienna (Vienna, Austria) for further analysis. We extracted DNA using the QIAmp DNA Mini Kit (QIAGEN, Vienna) according to the manufacturer's instructions for dried blood spots.

We tested all samples by a universal Leishmania PCR protocol using the LITSR/L5.8S primer pair (11) and following the protocol of Schönian et al. (12). To further discriminate species within the L. donovani/infantum complex, we ran 3 more PCR protocols for species differentiation: K26-PCR (13), cpbE/F-PCR (14,15), and HSP70-PCR (16) (online Technical Appendix, https://wwwnc.cdc.gov/EID/ article/24/11/17-2146-Techapp1.pdf).

\section{Ethics Considerations, Data Collection, and Data Analysis}

Because there was no operational, accredited ethics committee for the northern provinces of Syria, we submitted the study protocol to the ethics committee of the Medical University of Vienna. Oral consent was obtained from all patients before study-related procedures. Because of the extraordinary security situation and fear of causing a potential risk for the life of participants if there were a written record of personal information, in the light of activities by the rebel groups, investigators decided not to obtain written informed consent or any identifiable personal information in study-related documentation. The ethics committee approved this approach.

\section{Data Analysis}

We performed descriptive data analysis using JMP (https://www.jmp.com) and STATA/SE15.0 (https://www. stata.com). We used Microsoft Office (Microsoft, Redmond, WA, USA) to perform data visualization.

\section{Results}

\section{The MENTOR Initiative's Leishmaniasis Control Program in Northern Syria}

The MENTOR Initiative's first target regions were the provinces of Aleppo and Idlib; the group subsequently expanded its activities to Al-Raqqa, Al-Hasakah, and Hama. It was a challenge to reliably estimate the total population residing in the target regions because of the frequent and unpredictable movements of persons after military and political actions and the lack of a stable administrative control over the region. 
The MENTOR Initiative supported a network of $\approx 200$ HCCs, of which 161 HCCs provided reliable data over an extended follow-up period. These health facilities included HCCs and mobile clinics in each province (43 and 21 in Aleppo, 40 and 18 in Idlib, 7 and 12 in Hama, 7 and 5 in al-Raqqa, 8 and 0 in Al-Hasakah, respectively). The approximate geographic and population coverage in the target regions is provided in Table 1.

\section{Epidemiology of CL in Northern Syria}

The number of HCCs varied over the study period, mostly because of the changing security situation, which, in turn, led to movement of persons and, in some cases, loss of access to these health facilities. New cases of CL were recorded in HCCs in the provinces of Aleppo, Idlib, Hama, Al-Raqqa, and Al-Hasakah over varying periods, ranging from 2.5 months to 16 months (Table 1; Figures 1,2). The total number of new cases per year has been estimated based on the observation period and the estimated coverage of HCCs participating in the reporting system of the MENTOR Initiative. Data indicate a yearly incidence of 4,683-20,110 cases/year in these provinces. The total number of new CL patients was estimated at 64,498 cases in 2015 (Table 1).

Data indicate that the estimated incidence of CL was 5,883 cases/month at the onset of the study in the target region. This incidence further increased to $\approx 7,599$ cases/ month at its peak in February 2015. After the effective rollout of the leishmaniasis control program, the monthly incidence of CL was reduced to 2,476 cases/month in February 2016 (Figure 1).

Treatment outcome was assessed in 45,302 patients during the study period. Among those, $18 \%(8,312)$ were lost to follow-up, and therefore no outcome could be attributed. Among the remaining 36,990 patients, a favorable outcome was recorded by the treating healthcare workers in 35,931 (97.14\%, 95\% CI 96.96\%-97.30\%).

\section{Molecular-Epidemiologic Survey of CL at 2 Sentinel Sites}

Of the 249 patients who agreed to participate in this substudy, $104(42 \%)$ were female and 145 (58\%) were male, and $139(56 \%)$ had skin lesions suggestive for CL. The median age of participants was 11 years (interquartile range [IQR] 6-17 years), and the median body mass index was 19 (IQR 16-25) (Table 2). In Aleppo, only patients with CL participated in this study. However, the survey had to be prematurely discontinued in Aleppo after the recruitment of 55 participants because of the worsening security situation in the area at the time of the study.

Samples were taken from skin ulcers in 139 patients; 99 specimens were successfully shipped to Vienna (40 samples were lost as a result of security problems at the border crossing between Syria and Turkey). We confirmed Leishmania spp. infection in 93 (94\%) of the 99 samples using PCR. Most Leishmania infections were caused by strains of $L$. tropica $(\mathrm{n}=73,78 \%$ [95\% CI 69\%-86\%]). We detected L. major in 12 samples (13\% [95\% CI 7\%-21\%]). Seven infections were caused by $L$. infantum and 1 strain was identified as $L$. donovani (combined proportion of $L$. donovani/infantum complex $9 \%$ [95\% CI 4\%-16\%]). The relative proportion of $L$. infantum cases was higher in Idlib province $(\mathrm{n}=6,86 \%[95 \% \mathrm{CI} 42 \%-100 \%])$ than in Aleppo province $(\mathrm{n}=1,14 \%$ [95\% CI 0\%-58\%]) (Table 3).

We performed the K26 PCR successfully in 5 of 8 samples identified as belonging to the $L$. infantum/donovani complex. Retrieved bands were $\approx 280$ bp in 1 case (L. infantum, strain 268 ) and $\approx 370$ bp in 1 case (L. donovani, strain 275) (Figure 3, panel A); the other samples produced double bands at $\approx 800 / 900$ bp (Figure 3, panel B). We also used cpbEF-PCR on the L. donovani strain, producing bands of $\approx 400 \mathrm{bp}$, and on $1 \mathrm{~L}$. infantum strain, producing bands of $\approx 360$ bp (Figure 4). We performed HSP70 PCR with the $L$. donovani strain and $1 \mathrm{~L}$. infantum strain (Figure 5). To further confirm and investigate the identity of the $L$. donovani strain, we obtained DNA sequences for the $\approx 370$-bp band of the K26 PCR and the 2 fragments of the HSP70 PCR (together $\approx 1280 \mathrm{bp}$ ). The 368 -bp K26 sequence showed highest sequence similarity ( $358 / 371 \mathrm{bp})$ to a $L$. donovani strain isolated from a patient in Israel (GenBank accession no. HQ170543), and the 1,286-bp HSP70 fragment showed $100 \%$ similarity (562/562 bp) to the 562 -bp fragments available from $4 \mathrm{~L}$. donovani strains isolated from CL patients in Turkey close to the Syria border and 1 strain

\begin{tabular}{|c|c|c|c|c|c|c|c|}
\hline Province & $\begin{array}{l}\text { New cases observed } \\
\text { during study period }\end{array}$ & $\begin{array}{l}\text { Health } \\
\text { centers }\end{array}$ & $\begin{array}{l}\text { Mobile } \\
\text { clinics }\end{array}$ & $\begin{array}{c}\% \text { Program } \\
\text { coverage of area }\end{array}$ & $\begin{array}{l}\text { New cases } \\
\text { estimated* }^{*}\end{array}$ & $\begin{array}{c}\text { New cases reported } \\
\text { in } 2008(1,17)\end{array}$ & $\begin{array}{l}\text { Incidence } \\
\text { ratio }\end{array}$ \\
\hline Aleppo† & 12,296 & 43 & 21 & 70 & 13,174 & 18,603 & 0.7 \\
\hline Idlib† & 21,451 & 40 & 18 & 80 & 20,110 & 3,883 & 5.2 \\
\hline Hama† & 10,103 & 7 & 12 & 50 & 15,155 & 2,219 & 6.8 \\
\hline Al-Raqqał & 5,546 & 7 & 5 & 65 & 11,376 & 290 & 39.2 \\
\hline Al-Hasakah§ & 439 & 8 & 0 & 45 & 4,683 & 290 & 16.1 \\
\hline Total & 49,835 & 105 & 56 & & 64,498 & 25,285 & 2.6 \\
\hline
\end{tabular}

*Standardized cases for 1 year per province.

$\dagger 16$-month observation period.

79-month observation period.

§2.5-month observation period. 


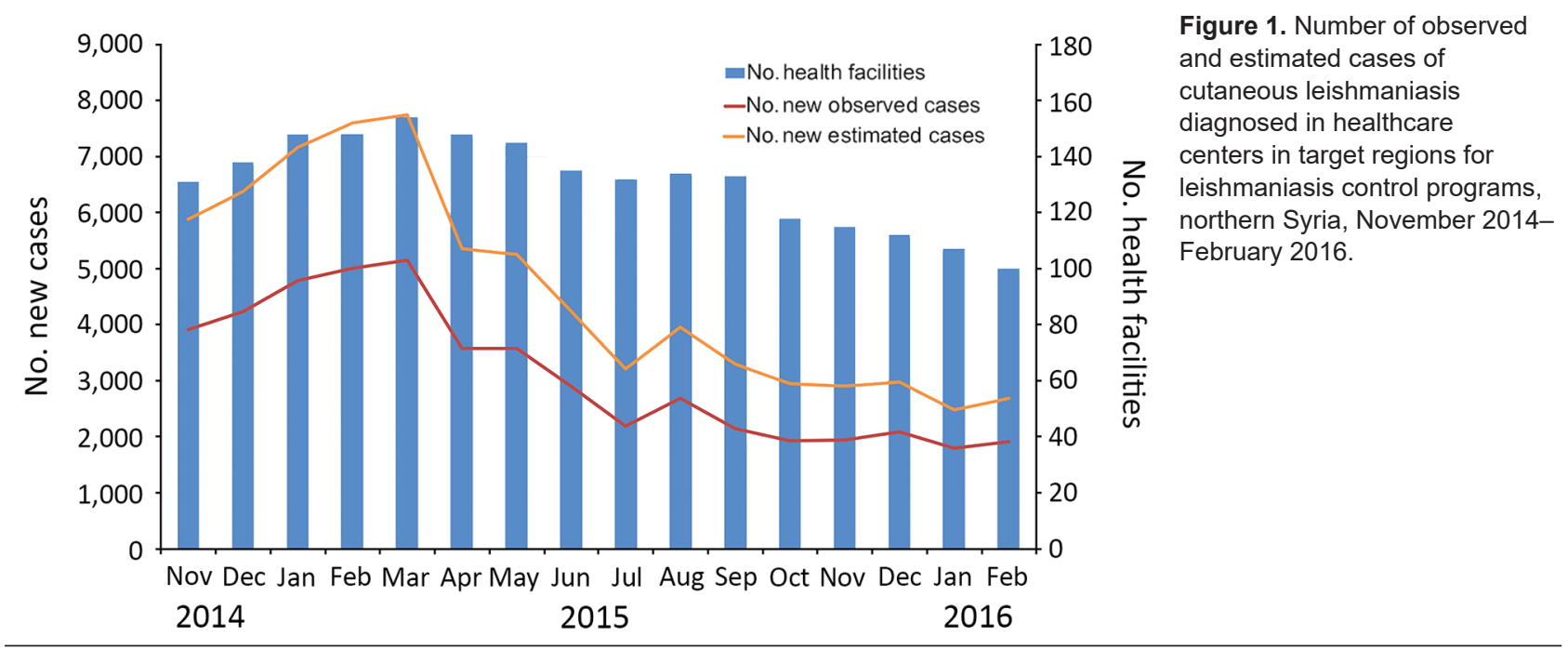

isolated from a CL patient in Cyprus (GenBank accession nos. KU949373-77) and $>99 \%$ similarity $(1,283 / 1,286$ bp) to the L. donovani strain pasteur (GenBank accession no. CP022643) and several other L. donovani strains. We submitted sequence data obtained in this study to GenBank (accession numbers pending).

\section{Cases of VL at Collaborating HCCs}

During the study period, 11 cases of VL were reported. Seven patients were male, and 7 were children $<5$ years of age (range 3 months-39 years). Seven patients were reported from Aleppo province and 4 from Idlib. Seven patients had ongoing fever and 1 patient high-grade fever. Anemia was reported for 6 patients and hepatosplenomegaly for 3 patients. Five patients additionally underwent bone marrow aspiration and showed positive PCR results for L. infantum infection. All patients with diagnoses of VL were treated systemically with pentavalent antimonials for 30 days, following current WHO guidelines (18).

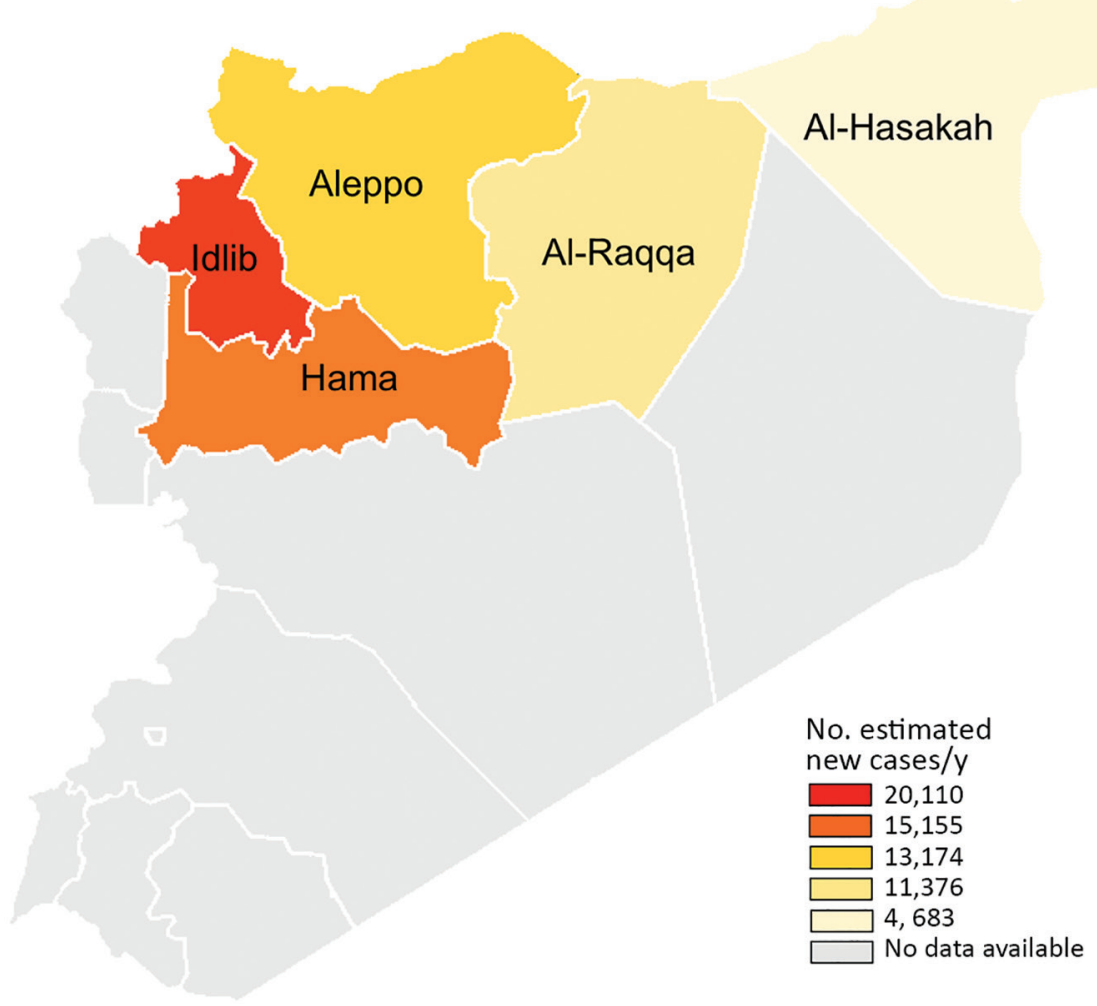

Figure 2. Target region for leishmaniasis control programs in northern Syria (color shading) and the number of estimated new cases of cutaneous leishmaniasis per year by province in this region. 
Table 2. Description of participants in the molecular epidemiologic substudy, northern Syria*

\begin{tabular}{lc}
\hline Characteristic & Total participants, $\mathrm{N}=\mathbf{2 4 9}$ \\
\hline Age, $\mathrm{y}$ & $11(6-17)$ \\
Median (IQR) & $107(43)$ \\
$\leq 10$ & $86(34.5)$ \\
$11-20$ & $22(8.8)$ \\
$21-30$ & $11(4.4)$ \\
$31-40$ & $7(2.8)$ \\
$41-50$ & $7(2.8)$ \\
$51-60$ & $9(3.6)$ \\
$\geq 61$ & $145(58.2)$ \\
Sex & $104(41.8)$ \\
$\mathrm{M}$ & $19(16-25)$ \\
$\mathrm{F}$ & $84(60.4)$ \\
\hline Body mass index, kg/m ${ }^{2}$ & $55(39.6)$ \\
Median (IQR) & $110(100)$ \\
\hline Presence of skin lesions, $\mathrm{n}=139$ & $\mathrm{NA}$ \\
Idlib & \\
Aleppo & \\
\hline Absence of skin lesions, $\mathrm{n}=110$ & \\
Idlib & \\
Aleppo & Values are no. (\%) except as indicated. IQR, interquartile range; NA, \\
not available.
\end{tabular}

\section{Discussion}

Syria has been a hotspot of leishmaniasis transmission for centuries. After a continuous decrease of leishmanial transmission in the past century, which was driven at least in part by vector control activities of the national malaria elimination campaign, WHO country data show a gradual but steady increase in annual case incidence from $\approx 14,000$ per year to an average of 27,825 reported CL cases/year before the onset of the civil war $(1,17)$ (Figure 6).

The governmental health system in Syria disintegrated in most parts of the northern provinces after the onset of the civil war; at the same time, reports from neighboring regions indicated a surge in leishmaniasis cases in refugee populations from Syria. The MENTOR Initiative set out to collaborate with most local leishmaniasis treatment centers in the target provinces, becoming, in practice, the only external collaborating institution for leishmaniasis control in the target regions. It is assumed that the number of HCCs did not greatly affect the overall measure of incidence, because patients seeking ongoing treatment courses went to other operational centers within the program when needed. Based on this information and the comprehensive reporting system, the
MENTOR Initiative was in a position to reliably assess and monitor the incidence of CL in northern Syria.

Thus, this survey provides epidemiologic data about the incidence of CL and VL in the war-affected regions of northern Syria since the onset of the civil war. Based on these data, a yearly incidence of 64,498 cases of CL was estimated, constituting a 2.6-fold increase in leishmaniasis transmission in the northern provinces over the $\approx 25,000$ cases of CL reported by the national authorities before the civil war, in 2008 (Table 1). This increase is in line with several anecdotal reports about an observed surge of leishmaniasis cases in refugees from Syria (2-4).

These data indicate a noteworthy change in the epidemiology of leishmaniasis transmission on a regional level. The provinces of Aleppo, Hama, and Idlib were the traditional hotspots of CL endemicity, whereas the provinces of Al-Raqqa and Al-Hasakah reported relatively few cases before the civil war (1). The survey results we report demonstrate, in contrast to prewar data, that the most dramatic increase in leishmaniasis transmission occurred in regions of previously low transmission intensity, including a nearly 40-fold increase in incidence of cases in AlRaqqa province. This change in the local epidemiology of leishmaniasis is most likely the result of a combination of factors, including large-scale population movement within the war-affected provinces and an increase in vector abundance as a result of an exponential increase in suitable sites for vector breeding caused by the barrel bombing of urban buildings, creating cracked walls and a buildup of domestic waste across cities and towns, conditions in which sand flies thrive and reproduce.

After the full implementation of this integrated leishmaniasis control program, estimated monthly case counts decreased progressively from March $2015(\mathrm{n}=7,743)$ to February $2016(\mathrm{n}=2,679)$. This change indicates a reduction of leishmaniasis transmission by $>2$-fold after the implementation of the control activities. Despite seasonal variations in incidence of leishmaniasis, most recent data indicate that control activities were able to reduce CL incidence to levels comparable to prewar conditions.

VL occurred sporadically during the study period; a total of 11 cases were reported by the participating HCCs. In contrast to the increases in CL, there was no notable increase in the reported incidence of VL in northern Syria at

\begin{tabular}{|c|c|c|c|c|}
\hline Category & L. tropica & L. major & L. infantum & L. donovani \\
\hline \multicolumn{5}{|l|}{ Province } \\
\hline Idlib & $50(83,71-92)$ & $3(5,1-14)$ & $6(10,4-21)$ & $1(2,0-9)$ \\
\hline Aleppo & $23(70,51-84)$ & $9(27,13-46)$ & $1(3,0-16)$ & $0(0,0-11)$ \\
\hline \multicolumn{5}{|l|}{ Sex } \\
\hline$M$ & $43(80,66-89)$ & $5(9,3-20)$ & $5(9,3-20)$ & $1(2,0-10)$ \\
\hline $\mathrm{F}$ & $30(77,61-89)$ & $7(18,8-34)$ & $2(5,1-17)$ & $0(0,0-9)$ \\
\hline Age, median (IQR) & $13(7-24)$ & $7.5(4.5-19)$ & $10(6-25)$ & $7(7-7)$ \\
\hline
\end{tabular}

*Values are no. $(\%, 95 \% \mathrm{Cl})$ except as indicated. IQR, interquartile range. 
Figure 3. A) Results of K26 PCR assay (13) on patient samples identified as belonging to the Leishmania infantum/donovani complex in study of leishmaniasis control programs in northern Syria. Lane 1, step marker; lanes 2 and $3, L$. infantum strain 268 with 3 and $6 \mu \mathrm{L}$ of DNA, respectively; lane $4, L$. donovani strain 275 with $3 \mu \mathrm{L}$ of DNA. B) Results of K26 PCR assay (13) on patient samples identified as belonging to the Leishmania infantum/donovani complex in

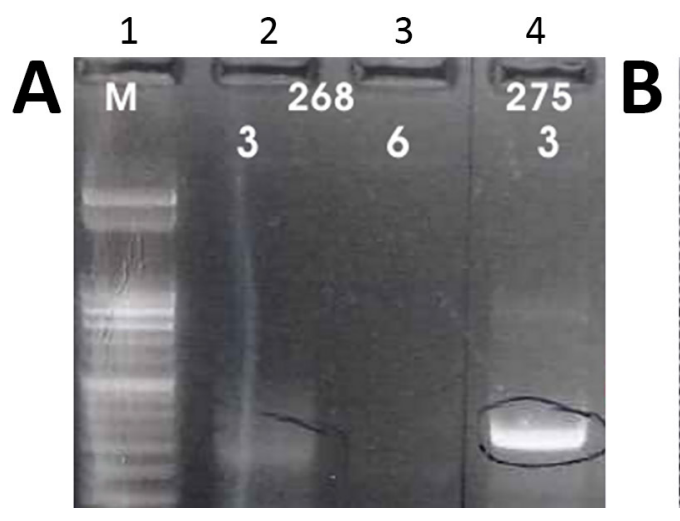
1 2 3 study of leishmaniasis control programs in northern Syria. Lane 1, step marker; lanes 2 and 3, L. infantum strain 278 with 3 and $6 \mu$ L of DNA, respectively.

the time of this study, compared with prewar data. However, asymptomatic cases may have occurred but were unreported within the communities, and in some HCCs, related

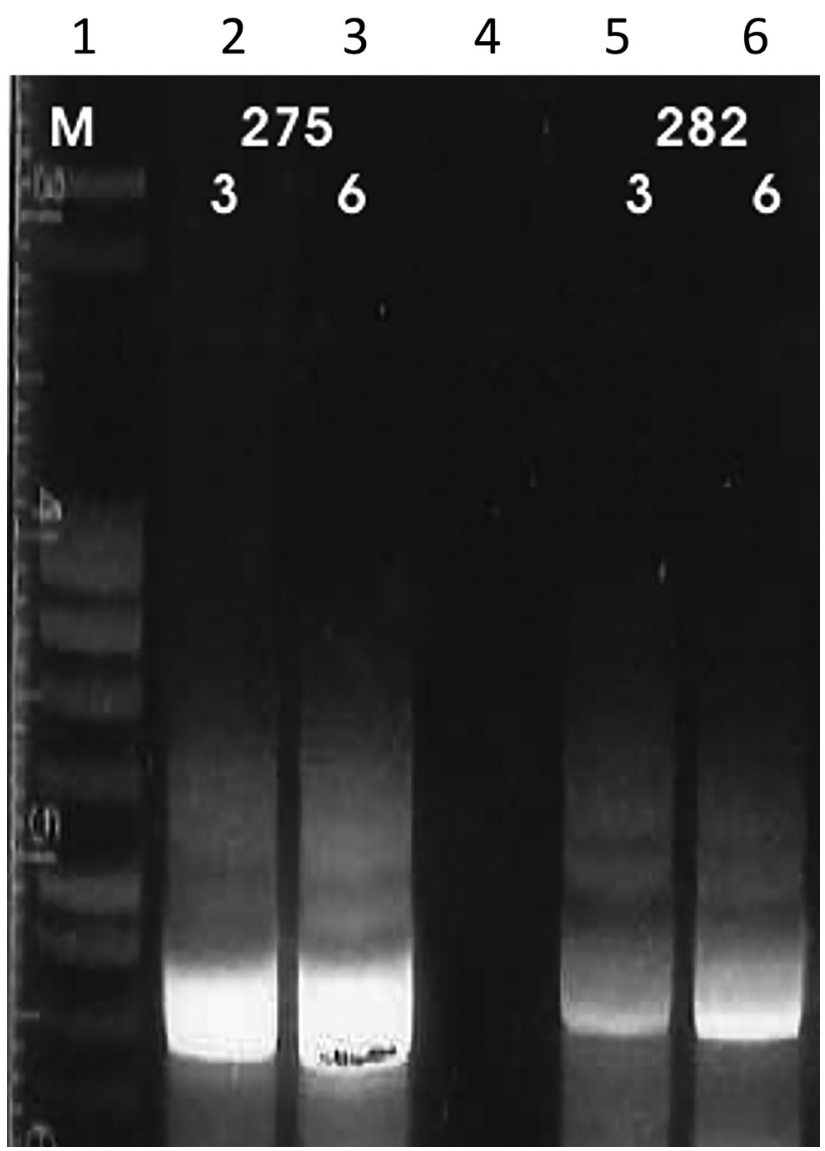

Figure 4. Results of cpb-EF PCR $(14,15)$ on patient samples identified as belonging to the Leishmania infantum/donovani complex in study of leishmaniasis control programs in northern Syria. Lane 1, step marker; lanes 2 and 3, L. donovani strain 275 with 3 and $6 \mu \mathrm{L}$ of DNA, respectively; lane 4 , negative control; lanes 5 and 6 , L. infantum strain 282 with 3 and $6 \mu \mathrm{L}$ of DNA, respectively. illnesses and deaths may have been misreported along with other unidentified causes of death.

Molecular analysis of leishmaniasis is recommended in high-resource settings to guide appropriate treatment. Previous data reported L. tropica as the main leishmanial species causing CL in northern Syria and L. major as the main species causing CL in southern Syria (19-22). This survey confirmed L. tropica as the predominant species in northern Syria, causing nearly $80 \%$ of cutaneous lesions. L. major was the second most prevalent species, accounting for $13 \%$ of all Leishmania species. $L$. infantum and $L$. donovani, which are considered classical pathogens for VL, were repeatedly confirmed in skin lesions of patients participating in this survey. In Syria, L. infantum has been reported previously as a causative agent of CL in humans (21); however, L. donovani had previously been isolated only from sand flies (23). Further, L. donovani has repeatedly been found in the neighboring countries Cyprus, Turkey, Iraq, and Israel (24-28). Recently, several cases of most likely autochthonous $L$. donovani infections have been reported from southeastern Anatolia in the direct vicinity of the border with Syria, and these were also cases of CL (29). In that study, L. tropica and L. infantum were described as the main causative agents of CL in Turkey, which fits well with our results for Syria. CL caused by $L$. donovani has also been documented from Cyprus (26). Moreover, numerous cases of CL caused by $L$. donovani have been documented from Sri Lanka (30). In summary, these molecular data demonstrate a surprising diversity of locally endemic Leishmania species causing cutaneous disease.

The challenging security situation led to several limitations in the conduct of the reported research activities. No accurate estimates of the actual population residing in the northern provinces were available because of the massive population movement within Syria, migration in neighboring countries, and casualties of the civil war. To address 


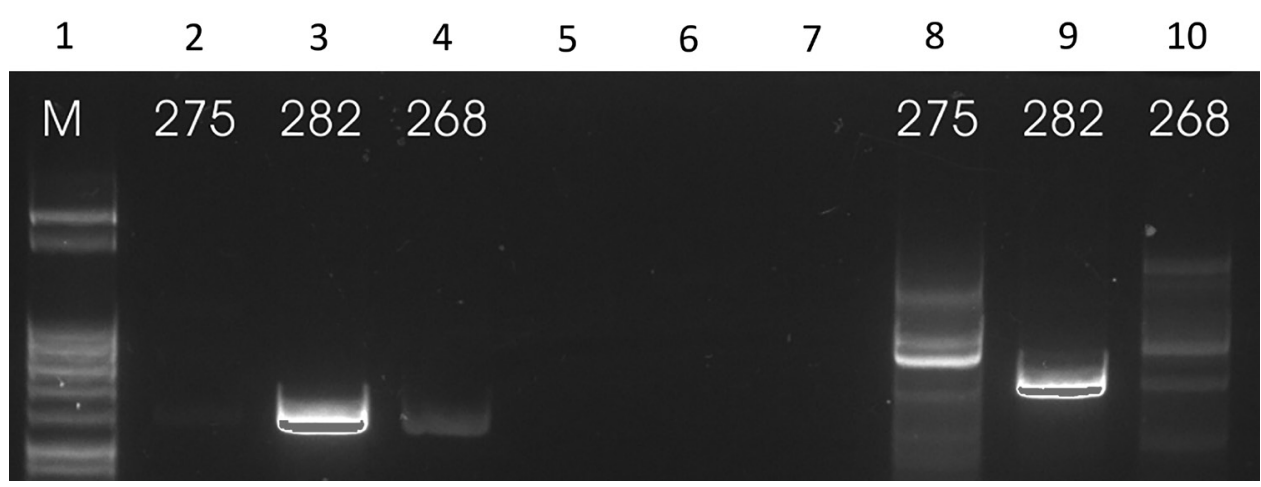

Figure 5. Results of HSP-70 PCR (16) on patient samples identified as belonging to the Leishmania infantum/ donovani complex in study of leishmaniasis control programs in northern Syria. Lane 1, step marker; lanes 2-4, N fragment of $L$. donovani strain 275 and $L$. infantum strains 282 and 268; lanes 5-7, blank; lanes 8-10, T fragment of $L$. donovani strain 275 and L. infantum strains 282 and 268.

these limitations, we relied on approximations used by international institutions for this analysis. The safety situation made direct access to the participating HCCs in Syria impossible for external MENTOR personnel. Therefore, the control program and the epidemiologic assessments had to rely on collaborating local staff. Local healthcare workers traveled often under precarious safety situations to the border region with Turkey to receive training and supplies for the control activities within Syria. Because of these constraints, a more detailed investigation was not feasible, and the investigation had to be limited to aspects deemed of highest importance for the implementation and evaluation of the ongoing leishmaniasis control program.

It was within this challenging safety situation that the MENTOR Initiative developed and deployed this large leishmaniasis control program. Epidemiologic data indicate that the control program started in a period of rapidly rising leishmaniasis transmission in northern Syria during the civil war. A further increase in leishmaniasis transmission was avoided. However, political stability and a stable security situation are required, above all, to further stabilize and successfully control leishmaniasis in northern Syria.

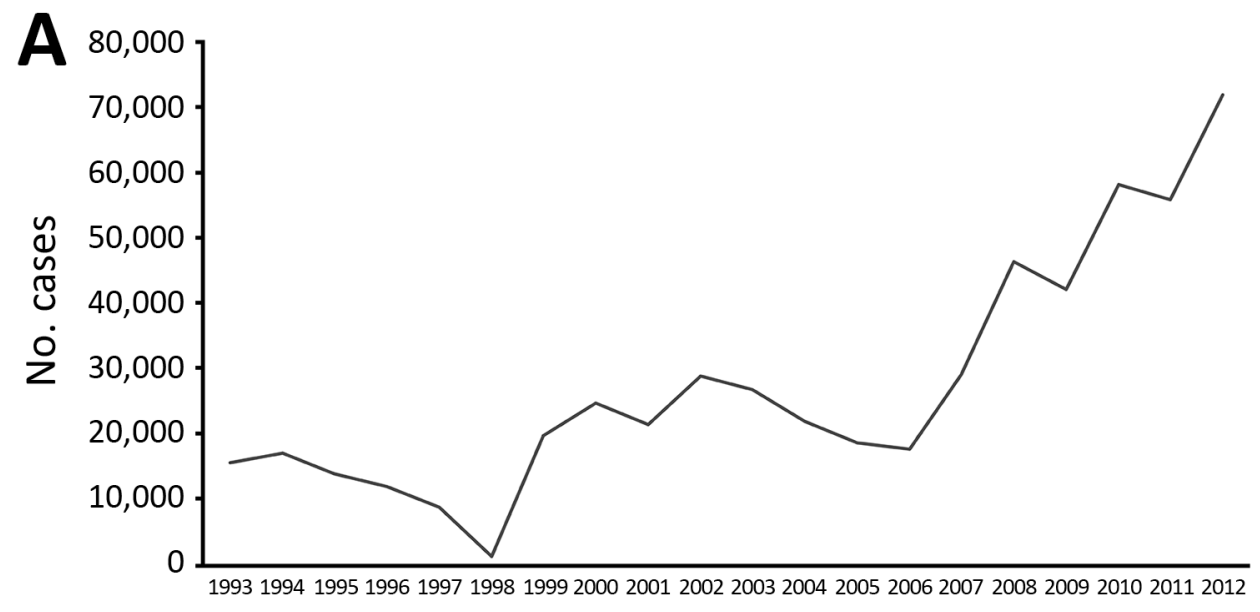

Figure 6. Cases of $(A)$ cutaneous and (B) visceral leishmaniasis in northern Syria during 1993-2012, before the onset of the civil war $(1,17)$.

B

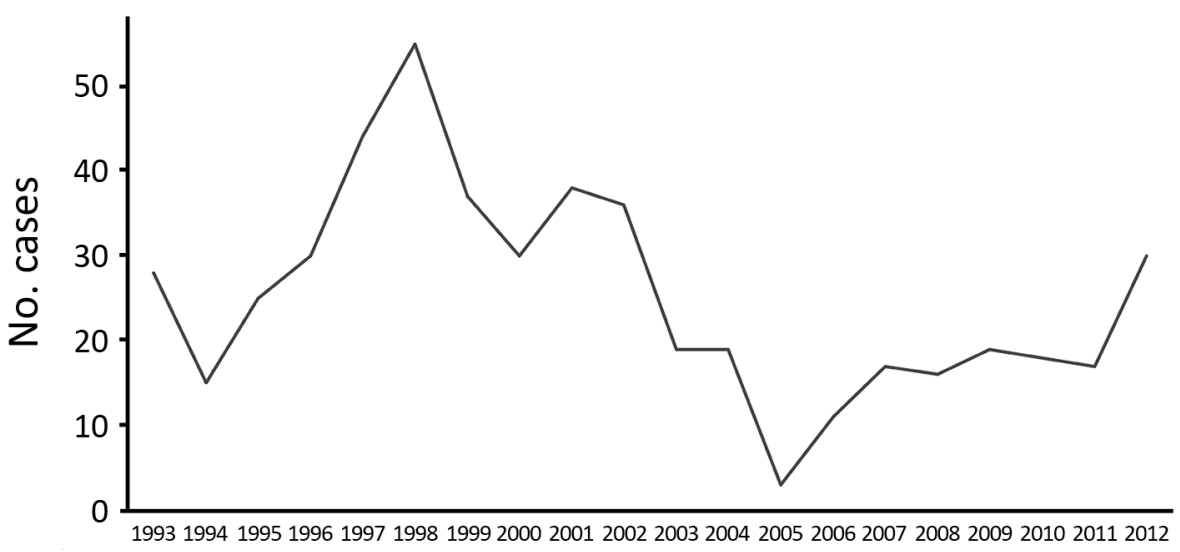




\section{Acknowledgments}

The authors acknowledge Kendra Dagg, Abdi Marouf, Maher Alkassem, Muhammad Sareer, and Bilal Saleem for their support in data collection and Iveta Häfeli for excellent technical assistance.

The US Agency for International Development and UK Department for International Development funded the leishmaniasis control work of the MENTOR Initiative.

\section{About the Author}

Dr. Rehman is a public health professional who is currently working with the Indus Hospital in Pakistan on a malaria control program. He has extensive experience in vectorborne disease control in Africa, Asia, and the Middle East. His research interests revolve around vectorborne diseases, especially malaria, leishmaniasis, and others.

\section{References}

1. World Health Organization. Global Health Observatory country views: Syrian Arab Republic, 1994-2010 [cited 2014 Aug 28]. http://www.who.int/leishmaniasis/resources/SYRIAN_ARAB_ REPUBLIC.pdf

2. Salam N, Al-Shaqha WM, Azzi A. Leishmaniasis in the Middle East: incidence and epidemiology. PLoS Negl Trop Dis. 2014;8:e3208. http://dx.doi.org/10.1371/journal.pntd.0003208

3. Hayani K, Dandashli A, Weisshaar E. Cutaneous leishmaniasis in Syria: clinical features, current status and the effects of war. Acta Derm Venereol. 2015;95:62-6. http://dx.doi.org/ $10.2340 / 00015555-1988$

4. Alasaad S. War diseases revealed by the social media: massive leishmaniasis outbreak in the Syrian spring. Parasit Vectors. 2013;6:94. http://dx.doi.org/10.1186/1756-3305-6-94

5. World Health Organization. Global strategic framework for integrated vector management; 2004 [cited 2017 Jan 2]. http://apps.who.int/iris/bitstream/handle/10665/68624/WHO_CDS_ CPE_PVC_2004_10.pdf?sequence $=1$

6. Boggild AK, Miranda-Verastegui C, Espinosa D, Arevalo J, Adaui V, Tulliano G, et al. Evaluation of a microculture method for isolation of Leishmania parasites from cutaneous lesions of patients in Peru. J Clin Microbiol. 2007;45:3680-4. http://dx.doi.org/10.1128/JCM.01286-07

7. Boggild AK, Miranda-Verastegui C, Espinosa D, Arevalo J, Martinez-Medina D, Llanos-Cuentas A, et al. Optimization of microculture and evaluation of miniculture for the isolation of Leishmania parasites from cutaneous lesions in Peru. Am J Trop Med Hyg. 2008;79:847-52.

8. Peruhype-Magalhães V, Machado-de-Assis TS, Rabello A. Use of the Kala-Azar Detect ${ }^{\circledR}$ and IT-LEISH ${ }^{\circledR}$ rapid tests for the diagnosis of visceral leishmaniasis in Brazil. Mem Inst Oswaldo Cruz. 2012;107:951-2. http://dx.doi.org/10.1590/ S0074-02762012000700019

9. Valencia BM, Veland N, Alba M, Adaui V, Arevalo J, Low DE, et al. Non-invasive cytology brush PCR for the diagnosis and causative species identification of American cutaneous leishmaniasis in Peru. PLoS One. 2012;7:e49738. http://dx.doi.org/10.1371/journal.pone.0049738

10. Boggild AK, Valencia BM, Espinosa D, Veland N, Ramos AP, Arevalo J, et al. Detection and species identification of Leishmania DNA from filter paper lesion impressions for patients with American cutaneous leishmaniasis. Clin Infect Dis. 2010;50:e1-6. http://dx.doi.org/10.1086/648730
11. El Tai NO, Osman OF, El Fari M, Presber W, Schönian G. Genetic heterogeneity of ribosomal internal transcribed spacer in clinical samples of Leishmania donovani spotted on filter paper as revealed by single-strand conformation polymorphisms and sequencing. Trans R Soc Trop Med Hyg. 2000;94:575-9. http://dx.doi.org/10.1016/S0035-9203(00)90093-2

12. Schönian G, Nasereddin A, Dinse N, Schweynoch C, Schallig HD, Presber W, et al. PCR diagnosis and characterization of Leishmania in local and imported clinical samples. Diagn Microbiol Infect Dis. 2003;47:349-58. http://dx.doi.org/10.1016/ S0732-8893(03)00093-2

13. Haralambous C, Antoniou M, Pratlong F, Dedet JP, Soteriadou K. Development of a molecular assay specific for the Leishmania donovani complex that discriminates $L$. donovani/Leishmania infantum zymodemes: a useful tool for typing MON-1. Diagn Microbiol Infect Dis. 2008;60:33-42. http://dx.doi.org/10.1016/ j.diagmicrobio.2007.07.019

14. Hide M, Bañuls AL. Species-specific PCR assay for L. infantum/ L. donovani discrimination. Acta Trop. 2006;100:241-5. http://dx.doi.org/10.1016/j.actatropica.2006.10.012

15. Zackay A, Nasereddin A, Takele Y, Tadesse D, Hailu W, Hurissa Z, et al. Polymorphism in the HASPB repeat region of east African Leishmania donovani strains. PLoS Negl Trop Dis. 2013;7:e2031. http://dx.doi.org/10.1371/journal.pntd.0002031

16. Van der Auwera G, Maes I, De Doncker S, Ravel C, Cnops L, Van Esbroeck M, et al. Heat-shock protein 70 gene sequencing for Leishmania species typing in European tropical infectious disease clinics. Euro Surveill. 2013;18:20543. http://dx.doi.org/ 10.2807/1560-7917.ES2013.18.30.20543

17. World Health Organization. Number of cases of cutaneous leishmaniasis reported; data by country, 2005-2016 [cited 2018 June 22]. http://apps.who.int/gho/data/view.main. NTDLEISHCNUMv

18. World Health Organization. Control of the leishmaniases. World Health Organ Tech Rep Ser. 2010;(949):xii-xiii, 1-186, back cover.

19. Belazzoug S, Pratlong F, Rioux JA. [A new zymodeme of Leishmania tropica, agent of Aleppo boil (Syria)]. Arch Inst Pasteur Alger. 1988;56:95-9.

20. Al-Nahhas SA, Kaldas RM. Characterization of Leishmania species isolated from cutaneous human samples from central region of Syria by RFLP analysis. ISRN Parasitol. 2013;2013:308726. http://dx.doi.org/10.5402/2013/308726

21. Haddad N, Saliba H, Altawil A, Villinsky J, Al-Nahhas S. Cutaneous leishmaniasis in the central provinces of Hama and Edlib in Syria: Vector identification and parasite typing. Parasit Vectors. 2015;8:524. http://dx.doi.org/10.1186/s13071-015-1147-0

22. Khiami A, Dereure J, Pratlong F, Martini A, Rioux JA. La leishmaniose cutane humaine à Leishmania major MON-26 aux environs de Damas (Syrie). Bull Soc Pathol Exot. 1991;84:340-4.

23. Rioux J, Leger N, Haddad N, Desjeux P. Natural infestation of Phlebotomus tobbi (Diptera, Psychodidae) by Leishmania donovani s. st. (Kinetoplastida, Trypanosomatidae) in Syria. Parassitologia. 1998;40(Suppl1):148.

24. Zackay A, Nasereddin A, Schnur L, Jaffe C. Molecular characterization of Leishmania donovani in Israel, GenBank accession no. HQ170543; 2016 [cited 2018 Jun 22]. https://www.ncbi.nlm.nih.gov/nuccore/315454626/

25. Alam MZ, Haralambous C, Kuhls K, Gouzelou E, Sgouras D, Soteriadou K, et al. The paraphyletic composition of Leishmania donovani zymodeme MON-37 revealed by multilocus microsatellite typing. Microbes Infect. 2009;11:707-15. http://dx.doi.org/10.1016/j.micinf.2009.04.009

26. Antoniou M, Haralambous C, Mazeris A, Pratlong F, Dedet JP, Soteriadou K. Leishmania donovani leishmaniasis in Cyprus. Lancet Infect Dis. 2008;8:6-7. http://dx.doi.org/10.1016/ S1473-3099(07)70297-9 
27. Bhattacharyya T, Boelaert M, Miles MA. Comparison of visceral leishmaniasis diagnostic antigens in African and Asian Leishmania donovani reveals extensive diversity and region-specific polymorphisms. PLoS Negl Trop Dis. 2013; 7:e2057. http://dx.doi.org/10.1371/journal.pntd.0002057

28. Gouzelou E, Haralambous C, Amro A, Mentis A, Pratlong F, Dedet JP, et al. Multilocus microsatellite typing (MLMT) of strains from Turkey and Cyprus reveals a novel monophyletic $L$. donovani sensu lato group. PLoS Negl Trop Dis. 2012;6:e1507. http://dx.doi.org/10.1371/journal.pntd.0001507

29. Özbilgin A, Harman M, Karakuş M, Bart A, Töz S, Kurt Ö, et al. Leishmaniasis in Turkey: visceral and cutaneous leishmaniasis caused by Leishmania donovani in Turkey.
Acta Trop. 2017;173:90-6. http://dx.doi.org/10.1016/ j.actatropica. 2017.05.032

30. Kariyawasam UL, Selvapandiyan A, Rai K, Wani TH, Ahuja K, Beg MA, et al. Genetic diversity of Leishmania donovani that causes cutaneous leishmaniasis in Sri Lanka: a cross sectional study with regional comparisons. BMC Infect Dis. 2017; 17:791. http://dx.doi.org/10.1186/s12879-017-2883-x

Address for correspondence: Michael Ramharter, University Medical Center Hamburg-Eppendorf, Department of Tropical Medicine, Bernhard Nocht Institute for Tropical Medicine and I. Department of Medicine, BernhardNocht Straße 74, 20359 Hamburg, Germany; email: ramharter@bnitm.de

\section{August 2017: Vectorborne Infections}

- Added Value of Next-Generation Sequencing for Multilocus Sequence Typing Analysis of a Pneumocystis jirovecii Pneumonia Outbreak

- Bartonella quintana, an Unrecognized Cause of Infective Endocarditis in Children in Ethiopia

- Characteristics of Dysphagia in Infants with Microcephaly Caused by Congenital Zika Virus Infection, Brazil, 2015

- Zika Virus Infection in Patient with No Known Risk Factors, Utah, USA, 2016

- Acute Febrile Illness and Complications Due to Murine Typhus, Texas, USA

- High Infection Rates for Adult Macaques after Intravaginal or Intrarectal Inoculation with Zika Virus

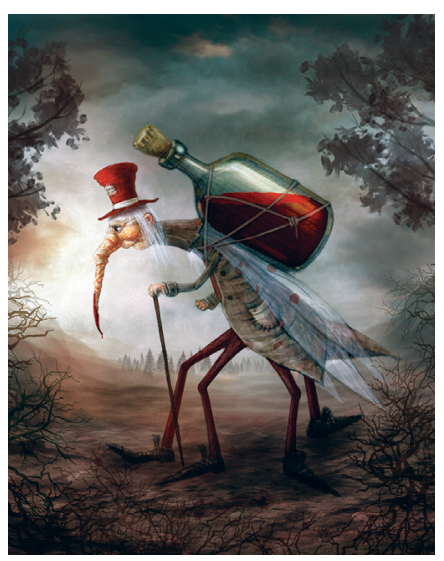

- Lyme Borreliosis in Finland, 1995-2014

- Characterization of Fitzroy River Virus and Serologic Evidence of Human and Animal Infection

- Genomic

Characterization of Recrudescent Plasmodium malariae after Treatment with Artemether/ Lumefantrine

- Molecular Characterization of Corynebacterium diphtheriae Outbreak Isolates, South Africa, March-June 2015

- Clinical Laboratory Values as Early Indicators of Ebola Virus Infection in Nonhuman Primates

- Global Spread of Norovirus Gll. 17 Kawasaki 308, 2014-2016

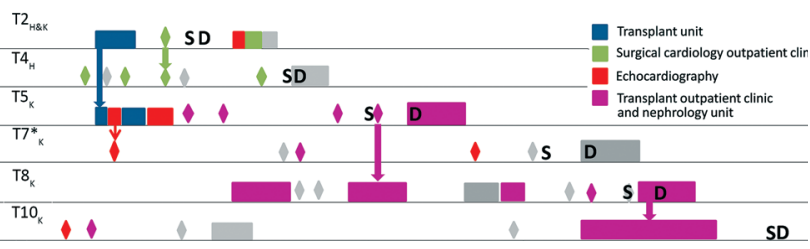

- Maguari Virus Associated with Human Disease

- Human Infection with Highly Pathogenic Avian Influenza $\mathrm{A}(\mathrm{H} 7 \mathrm{~N} 9)$ Virus, China

- Human Metapneumovirus and Other Respiratory Viral Infections during Pregnancy and Birth, Nepal

- Preliminary Epidemiology of Human Infections with Highly Pathogenic Avian Influenza A(H7N9) Virus, China, 2017

- Real-Time Evolution of Zika Virus Disease Outbreak, Roatán, Honduras

- Clonal Expansion of New Penicillin-Resistant Clade of Neisseria meningitidis Serogroup W Clonal Complex 11, Australia

- Genesis of Influenza A(H5N8) Viruses

- Density-Dependent Prevalence of Francisella tularensis in Fluctuating Vole Populations, Northwestern Spain

- Occupational Exposures to Ebola Virus in Ebola Treatment Center, Conakry, Guinea

- West Nile Virus Outbreak in Houston and Harris County, Texas, USA, 2014

- Serologic Evidence of Scrub Typhus in the Peruvian Amazon

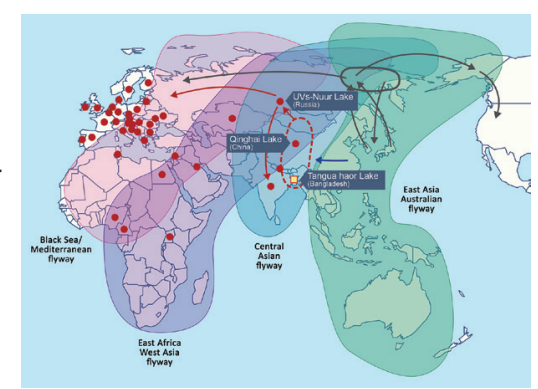

